Check for updates

Cite this: Mater. Adv., 2021, 2, 2036

Received 3rd December 2020, Accepted 17th February 2021

DOI: 10.1039/d0ma00949k

rsc.li/materials-advances

\title{
Sample dependent performance of aqueous copper hexacyanoferrate/zinc batteries $\dagger$
}

\author{
Solveig Kjeldgaard, ${ }^{a b}$ Marnix Wagemaker, (D) ${ }^{c}$ Bo Brummerstedt Iversen $\left(\mathbb{D}^{\mathrm{b}}\right.$ and \\ Anders Bentien (D)*a
}

\begin{abstract}
In this work, we investigate factors affecting the capacity retention of aqueous copper hexacyanoferrate/ $\mathrm{Zn}$ batteries. We compare the performance of four different copper hexacyanoferrate (CuHCF) samples as cathode in CuHCF/Zn cells with $\mathrm{Na}_{2} \mathrm{SO}_{4}$ and $\mathrm{ZnSO}_{4}$ based electrolytes at different $\mathrm{pH}$. In $\mathrm{Na}_{2} \mathrm{SO}_{4}$ electrolyte, the capacity retention is improved at lower $\mathrm{pH}$, whereas cells with $\mathrm{ZnSO}_{4}$ electrolyte perform similarly at pH 2 and 4. Finally, we show that the performance of CuHCF/Zn cells is highly dependent on the CuHCF sample, underlining the necessity for detailed synthesis description and thorough structural characterization of electrode materials.
\end{abstract}

\section{Introduction}

There is a global drive to replace fossil fuels with solar and wind powered renewable energy sources. The major challenge of incorporating a larger proportion of energy from renewable energy sources in the grid is the inherent intermittent nature of these, and the transition therefore relies on the expansion of stationary energy storage. For stationary energy storage, energy density is less important, while cost and lifetime are main drivers. Here, aqueous based rechargeable batteries are interesting for a number of reasons: (i) raw material sourcing can be decoupled from automotive batteries. (ii) Aqueous electrolytes have a high ionic conductivity compared to organic electrolytes, enabling thicker electrodes, less complex cell design and lower production cost. (iii) Aqueous based electrolytes have higher safety and lower environmental impact. Nonetheless, the number of elements that are redox active within the electrochemical window of water as well as being abundant and low cost is limited, and include metals such as $\mathrm{Cu}, \mathrm{Mn}, \mathrm{Fe}, \mathrm{Zn}, \mathrm{Ni}$, Ti and $\mathrm{Cr}^{1,2}$

Zinc anodes are attractive due to the high elemental abundance and low cost of zinc. Furthermore, zinc is compatible with aqueous electrolytes, as opposed to metals such as magnesium, calcium and aluminum. Zinc has a high volumetric energy density of $5855 \mathrm{~mA} \mathrm{~h} \mathrm{~cm}{ }^{-3}$ and a low electrode potential of $-0.76 \mathrm{~V} v \mathrm{~s}$. SHE in aqueous solutions. Many research efforts have been invested in the development of aqueous rechargeable $\mathrm{Zn}$-ion batteries. However, it remains a challenge to identify a suitable cathode

\footnotetext{
${ }^{a}$ Department of Biological and Chemical Engineering, Aarhus University, Denmark. E-mail: bentien@bce.au.dk

${ }^{b}$ Department of Chemistry, Aarhus University, Denmark

${ }^{c}$ Department of Radiation Science \& Technology, Technical University Delft, The Netherlands

$\dagger$ Electronic supplementary information (ESI) available. See DOI: 10.1039/d0ma00949k
}

material with high rate capability and good cycle life. Rechargeable $\mathrm{MnO}_{2} / \mathrm{Zn}$ batteries have been investigated intensively in both alkaline ${ }^{3}$ and neutral/mildly acidic $^{4-6}$ electrolyte. Other cathode materials like vanadium oxide ${ }^{7}$ have also been investigated, while in particular Prussian Blue Analogues ${ }^{8-14}$ appear promising.

Prussian Blue Analogues (PBA) are a large family of transition metal hexacyanometallates with the general structural formula $\mathrm{A}_{x} \mathrm{P}\left[\mathrm{R}(\mathrm{CN})_{6}\right]_{1-y}$ where $\mathrm{A}$ is an insertion ion, often potassium or sodium, $\mathrm{P}$ and $\mathrm{R}$ are transition metals and $y$ is the number of $\left[\mathrm{R}(\mathrm{CN})_{6}\right]^{3-14-}$ vacancies. Generally, PBA belong to cubic space group $F m \overline{3} m,{ }^{15-20}$ although for PBA with very high A content (A: Na, K), also rhombohedral ${ }^{21-24}$ and monoclinic ${ }^{25,26}$ structures are often reported. The cubic unit cell structure is shown in Fig. 1.

PBA have a cage-like structure with wide channels allowing for insertion of even large intercalation ions, and PBAs have proved to be able to intercalate even multivalent ions reversibly

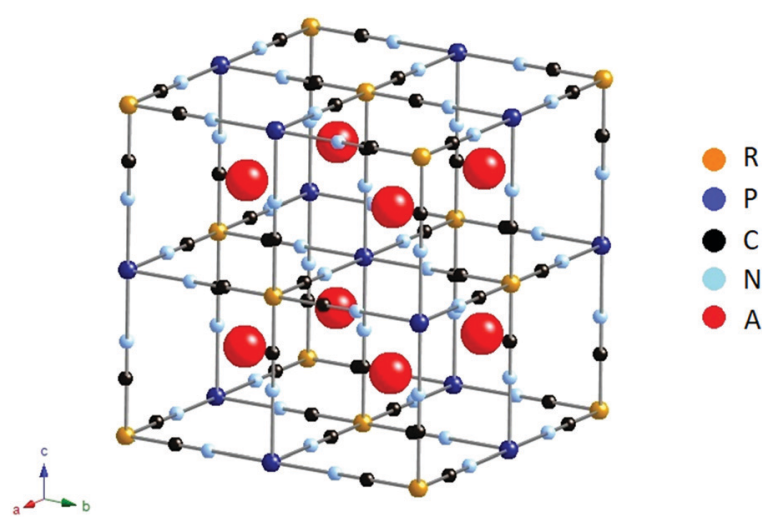

Fig. 1 Idealized structure of PBA $A_{x} P\left[R(C N)_{6}\right]_{1-y}$ with $y=0$ (no vacancies), cubic space group $F m \overline{3} m$. Figure made using CrystalMaker. 
with fast kinetics in aqueous solution. ${ }^{27}$ The open framework structure of PBA ensures rapid ionic conduction, enabling remarkably high rate capability. ${ }^{28,29}$ PBA can be prepared by a simple, scalable and low cost co-precipitation synthesis made from abundant and non-toxic elements.

For aqueous batteries, especially copper hexacyanoferrate (CuHCF) has been considered as cathode material due to its high redox potential that is just below the oxygen evolution potential. Aqueous $\mathrm{CuHCF} / \mathrm{Zn}$ batteries have a high cell potential of approximately $1.7 \mathrm{~V}$, which in practice is an almost full utilization of the electrochemical window of water. A commonly reported stoichiometry for CuHCF is $\mathrm{Cu}^{\mathrm{II}}\left[\mathrm{Fe}^{\mathrm{III}}(\mathrm{CN})_{6}\right]_{2 / 3}$ with $1 / 3$ $\left[\mathrm{Fe}(\mathrm{CN})_{6}\right]^{3-}$ vacancies, which is likely due to charge balancing of the framework. This stoichiometry is prevalent also for PBA with other transition metals in similar oxidation state. ${ }^{30,31}$

The existence of $\left[\mathrm{Fe}(\mathrm{CN})_{6}\right]^{3-/ 4-}$ vacancies can possibly increase the ionic conduction, and may play a crucial role in the diffusion pathway, especially for larger insertion ions. In a perfect lattice, the ions are conducted through the $\langle 100\rangle$ channels. A vacancy gives an effective diameter of approximately 8.5 $\AA$, which is larger than the distance between neighboring $\mathrm{R}$ sites. $^{32,33}$ Therefore, adjacent vacancies can connect to form channels, offering an alternative diffusion route. Assuming a random vacancy distribution, the percolation threshold for the face centered cubic (fcc) sublattice of the R site is approximately $0.2,{ }^{34}$ however, as shown by Simonov et al., vacancy distribution in PBA tend to be non-random. ${ }^{33}$ For PBA with composition $\left[\mathrm{P}^{\mathrm{II}} \mathrm{R}^{\mathrm{III}}(\mathrm{CN})_{6}\right]_{2 / 3}$, such as CuHCF, the number of vacancies is high enough that the vacancies form an interconnected network regardless of the vacancy distribution being random or ordered. Studies have shown that whereas small cations are conducted through the $\langle 100\rangle$ channels, larger cations move through vacant $\left[\mathrm{Fe}(\mathrm{CN})_{6}\right]^{3-/ 4-}$ positions, implying that vacancies play an important role in ion conduction. ${ }^{35,36}$

The most commonly reported electrolyte salt for $\mathrm{PBA} / \mathrm{Zn}$ cells is $\mathrm{ZnSO}_{4}{ }^{8,10-12,14,36,37}$ but also sodium based electrolyte salts such as $\mathrm{Na}_{2} \mathrm{SO}_{4}{ }^{9,12,13}$ are commonly reported. Previous studies have reported low cycle life due to $\mathrm{Zn}$-ion poisoning of the cathode, and Na-ion based electrolyte has been proposed as a way to minimize Zn-ion poisoning. ${ }^{13}$ Nonetheless, in fully discharged $\mathrm{PBA} / \mathrm{Zn}$ cells, $\mathrm{Zn}^{2+}$ is dissolved in the electrolyte and if this concentration needs to be significantly lower than that of the $\mathrm{Na}^{+}$, this will be the limiting factor for the cell capacity. For this reason, the approach of using sodium intercalation in PBA/Zn cells is a severe limitation of further technological development of $\mathrm{PBA} / \mathrm{Zn}$ based cells.

$\mathrm{PBA} / \mathrm{Zn}$ cells often use slightly acidic electrolyte. Zinc dendrite formation is more pronounced in alkaline electrolyte than in neutral electrolytes, ${ }^{7,38,39}$ and also PBA are often used with acidic electrolyte. In a study from 1992, Stilwell et al. investigated the factors affecting the stability of Prussian Blue films, reporting a remarkable increase in film stability in acidic electrolyte, achieving lifetimes of 100000 cycles at $\mathrm{pH} 2-3 .^{40}$ It has previously been reported that PBA are unstable in alkaline electrolyte; several studies report conversion of NiHCF into nickel oxides at $\mathrm{pH}>8,{ }^{41-44}$ and similar degradation is expected for other PBA. To the best of our knowledge, there are no comprehensive studies exploring the optimal $\mathrm{pH}$ of the electrolyte.

In literature, the reported capacity retention of $\mathrm{CuHCF} / \mathrm{Zn}$ cells with $\mathrm{ZnSO}_{4}$ based electrolyte varies considerably. The capacity retention of $\mathrm{CuHCF} / \mathrm{Zn}$ cells can be improved by using a lower concentration of $\mathrm{ZnSO}_{4},{ }^{45}$ and also the C-rate can affect capacity retention; Kasiri et al. observe a phase transition of CuHCF after 200 cycles at $1 \mathrm{C}$, and after 600 cycles at $5 \mathrm{C} .^{45}$ However, the difference in capacity retention of $\mathrm{CuHCF} / \mathrm{Zn}$ cells may also be due to differences in the CuHCF structure. PBA provide a large structural versatility, which can be expected to have a large impact on the electrochemical performance.

In the present study, we investigate factors affecting the electrochemical performance of aqueous $\mathrm{CuHCF} / \mathrm{Zn}$ cells. The voltage range has a large impact on the capacity retention of $\mathrm{CuHCF} / \mathrm{Zn}$ cells, with the best capacity retention achieved with voltage range 1.4-2.0 V. We test $\mathrm{CuHCF} / \mathrm{Zn}$ cells in $\mathrm{ZnSO}_{4}$ and $\mathrm{Na}_{2} \mathrm{SO}_{4}$ based electrolytes at different $\mathrm{pH}$. The performance of $\mathrm{CuHCF} / \mathrm{Zn}$ cells with $\mathrm{Na}_{2} \mathrm{SO}_{4}$ based electrolyte is highly dependent on $\mathrm{pH}$, with better performance at lower $\mathrm{pH}$, which is not the case for $\mathrm{CuHCF} / \mathrm{Zn}$ cells with $\mathrm{ZnSO}_{4}$ based electrolyte. Decreased capacity retention of cells with $\mathrm{Na}_{2} \mathrm{SO}_{4}$ based electrolyte at higher $\mathrm{pH}$ is due to increased PBA dissolution. PBA dissolution should be understood as dissolution into $\mathrm{M}^{2+}$ and $\left[\mathrm{Fe}(\mathrm{CN})_{6}\right]^{3-/ 4-}$, and is not related to cyanide release. Studies have proved that the cyanide release is low across a wide $\mathrm{pH}$ range, ${ }^{46}$ with the cyanide release being at its minimum at pH $5\left(20.01 \mu \mathrm{g} \mathrm{g}^{-1}\right)$ and maximum at $\mathrm{pH} 1\left(47.47 \mu \mathrm{g} \mathrm{g}^{-1}\right) .^{47}$ Contrary to previous reports, the capacity retention is not improved by using $\mathrm{Na}_{2} \mathrm{SO}_{4}$ based electrolyte rather than $\mathrm{ZnSO}_{4}$ based electrolyte. Finally, we show that $\mathrm{CuHCF} / \mathrm{Zn}$ cell performance is highly dependent on the CuHCF sample, and large differences in performance are observed even for CuHCF samples that are almost indistinguishable with state-of-the-art analytical methods.

\section{Experimental}

\section{Synthesis}

The synthesis and structural characterization of CuHCF has been described in detail previously. ${ }^{48}$ Briefly, CuHCF was prepared by co-precipitation using programmable syringe pumps. The two precursor solutions were added simultaneously to a flask containing $50 \mathrm{~mL}$ of water with a flow rate of $4 \mathrm{~mL} \mathrm{~min} \mathrm{~min}^{-1}$. Following precipitation, samples were left in the mother liquor for a variable period. Finally, the precipitate was washed with water and dried. An overview of synthesis details for all samples in the current study is included in Table 1. Details on structural characterization including ICP-OES, PXRD, TEM and Mössbauer spectroscopy can be found elsewhere. ${ }^{48}$

We test four different CuHCF samples with varying synthesis parameters: samples C, G, I and $\mathrm{K}$. The sample names correspond with naming from our previous structural study. ${ }^{48}$ Sample $\mathrm{C}$ was prepared by co-precipitation of $0.1 \mathrm{M} \mathrm{CuSO}_{4}$ and $0.1 \mathrm{M} \mathrm{K}_{3} \mathrm{Fe}(\mathrm{CN})_{6}$. In synthesis $\mathrm{G}, \mathrm{KCl}$ was added to the $50 \mathrm{~mL}$ water, making a $2.5 \mathrm{M}$ solution. Samples C, G and K were made from equimolar precursor solutions, and sample I was made with an excess of $\mathrm{K}_{3} \mathrm{Fe}(\mathrm{CN})_{6}$. 
Table 1 Syntheses details. The (final) target oxidation state is $\mathrm{Cu}^{\prime \prime}\left[\mathrm{Fe}{ }^{\prime \prime \prime}(\mathrm{CN})_{6}\right]$ for all samples

\begin{tabular}{lllllll}
\hline Sample & Reagents & Conc. $(\mathrm{M})$ & Flow rate & Atm & $T\left({ }^{\circ} \mathrm{C}\right)$ & Aging \\
\hline $\mathrm{C}$ & $\mathrm{CuSO}_{4}$ & 0.1 & $4 \mathrm{~mL} \mathrm{~min}^{-1}$ & $\mathrm{~N}_{2}$ & 70 & 2 h heat, \\
& $\mathrm{K}_{3} \mathrm{Fe}(\mathrm{CN})_{6}$ & 0.1 & & & & $2 \mathrm{~h}$ stir \\
$\mathrm{G}$ & $\mathrm{CuSO}_{4}$ & 0.1 & $4 \mathrm{~mL} \mathrm{~min}^{-1}$ & - & 70 & $2 \mathrm{~h}$ heat, \\
& $\mathrm{K}_{3} \mathrm{Fe}(\mathrm{CN})_{6}$ & 0.1 & & & & $2 \mathrm{~h}$ stir \\
& $\mathrm{KCl}$ & 2.5 & & & & \\
$\mathrm{I}$ & $\mathrm{CuSO}_{4}$ & 0.1 & $4 \mathrm{~mL} \mathrm{~min}^{-1}$ & - & 70 & $2 \mathrm{~h}$ heat, \\
& $\mathrm{K}_{3} \mathrm{Fe}(\mathrm{CN})_{6}$ & 0.15 & & & & 2 h stir \\
$\mathrm{K}$ & $\mathrm{CuCl}_{2}$ & 0.1 & $1 \mathrm{~mL} \mathrm{~min}^{-1}$ & $\mathrm{~N}_{2}$ & $\mathrm{RT}$ & $18 \mathrm{~h}$ stir, \\
& $\mathrm{K}_{4} \mathrm{Fe}(\mathrm{CN})_{6}$ & 0.1 & & & & $\mathrm{H}_{2} \mathrm{O}_{2}$
\end{tabular}

Sample $\mathrm{K}$ was prepared from $0.1 \mathrm{M} \mathrm{CuCl}_{2}$ and $0.1 \mathrm{M} \mathrm{K}_{4} \mathrm{Fe}(\mathrm{CN})_{6}$, initially yielding $\mathrm{Cu}^{\mathrm{II}} \mathrm{Fe}^{\mathrm{II}}(\mathrm{CN})_{6}$ and subsequently oxidized to $\mathrm{Cu}^{\mathrm{II}} \mathrm{Fe}^{\mathrm{III}}(\mathrm{CN})_{6}$ using excess hydrogen peroxide.

\section{Electrode preparation}

Powdered CuHCF was mixed with carbon black (Super C45, Timcal) and polyvinylidene fluoride (PVDF) with a dry weight ratio of $70: 20: 10$. $N$-Methyl-2-pyrrolidone (NMP) was added to obtain a slurry that was stirred for two hours, and subsequently spread onto carbon paper and dried in a vacuum oven at $70{ }^{\circ} \mathrm{C}$ overnight. Circular electrodes with a mass loading of approximately 5-10 mg active material were punched out.

\section{Electrochemical characterization}

Cells were cycled galvanostatically using coin cells type CR2032 with $\mathrm{Zn}$ foil anode (Alfa Aesar, $0.25 \mathrm{~mm}$ thick, 99.98\%) and glass fiber separator (Whatman GF/D). The electrolytes were $1 \mathrm{M}$ $\mathrm{ZnSO}_{4}$ and $1 \mathrm{M} \mathrm{Na}_{2} \mathrm{SO}_{4}$, with $\mathrm{pH} 2$ and 4 adjusted by addition of $\mathrm{H}_{2} \mathrm{SO}_{4}$. The volume of electrolyte added was approximately $0.14 \mathrm{~mL}$. All cells were cycled with a current rate of $50 \mathrm{~mA} \mathrm{~g}^{-1}$, corresponding to approximately $1 \mathrm{C}$.

\section{Results and discussion}

All CuHCF samples belong to cubic space group $F m \overline{3} m$, the idealized structure (no vacancies, $y=0$ ) is seen in Fig. 1. The stoichiometry and particle size of the different samples is reported in Table 2 .

The theoretical capacity for anhydrous $\operatorname{KCuFe}(\mathrm{CN})_{6}$ with no vacancies is $85 \mathrm{~mA} \mathrm{~h} \mathrm{~g}{ }^{-1}$. The CuHCF samples in the current study have approximately $1 / 3\left[\mathrm{Fe}(\mathrm{CN})_{6}\right]^{3-}$ vacancies, which are occupied by water. Water can also be present in the interstitial (A)

Table 2 Structural details including stoichiometry and size by PXRD and TEM

\begin{tabular}{llll}
\hline Sample & Stoichiometry & Size $(\mathrm{PXRD})[\mathrm{nm}]$ & Size $(\mathrm{TEM})[\mathrm{nm}]$ \\
\hline $\mathrm{C}$ & $\mathrm{K}_{0.24} \mathrm{Cu}\left[\mathrm{Fe}(\mathrm{CN})_{6}\right]_{0.69}$ & 33.0 & 30 \\
$\mathrm{G}$ & $\mathrm{K}_{0.18} \mathrm{Cu}\left[\mathrm{Fe}(\mathrm{CN})_{6}\right]_{0.69}$ & 53.3 & 80 \\
$\mathrm{I}$ & $\mathrm{K}_{0.10} \mathrm{Cu}\left[\mathrm{Fe}(\mathrm{CN})_{6}\right]_{0.68}$ & 37.3 & 48 \\
K & $\mathrm{K}_{0.86} \mathrm{Cu}\left[\mathrm{Fe}(\mathrm{CN})_{6}\right]_{0.72}$ & 31.9 & 24
\end{tabular}

sites, and the exact water content is dependent on temperature and humidity. The calculated theoretical capacity is $57 \mathrm{~mA} \mathrm{~h} \mathrm{~g}^{-1}$ based on a composition of $\mathrm{KCu}\left[\mathrm{Fe}(\mathrm{CN})_{6}\right]_{2 / 3} \cdot 4 \mathrm{H}_{2} \mathrm{O}$, which agrees well with previous studies on CuHCF. ${ }^{16}$

\section{Effect of voltage range on capacity retention}

Choosing the upper and lower cut-off voltage for charging and discharging is a trade-off between several parameters. Utilization of the full capacity of the battery normally requires high and low cut-off voltages, nonetheless, high cut-off voltages may lead to unwanted side reactions like hydrogen and oxygen evolution. Additionally, attempts to utilize the full capacity may also lead to structural stress on the cathode material as intercalation ions are fully extracted/inserted by full charge/discharge.

$\mathrm{CuHCF} / \mathrm{Zn}$ cells with $1 \mathrm{M} \mathrm{ZnSO}_{4}$ electrolyte at $\mathrm{pH} 4$ were cycled using voltage ranges $1.4-2.0 \mathrm{~V}, 1.4-2.05 \mathrm{~V}, 0.8-1.9 \mathrm{~V}$ and 1.4-1.9 V. Fig. 2 shows capacity/voltage plots, while Fig. 3 shows the discharge capacity as a function of cycle number.

From Fig. $2 \mathrm{c}$ and $\mathrm{d}$ it is seen that the charging plateau is not yet completed at $1.9 \mathrm{~V}$, which becomes even more pronounced for higher cycle numbers. When the maximum cutoff voltage is increased to $2.0 \mathrm{~V}$ (Fig. 2a) or $2.05 \mathrm{~V}$ (Fig. 2b) the cells appear to reach full charge. When the lower cutoff voltage is set to $0.8 \mathrm{~V}$, another discharge plateau is observed around $1.0 \mathrm{~V}$ to $1.2 \mathrm{~V}$, which gets more pronounced with higher cycle number (Fig. 2c). When the lower cutoff voltage is limited to $1.4 \mathrm{~V}$ (Fig. 2a, b and d), the initial discharge capacity is lower, but the capacity retention is improved. The additional plateau at approximately $1.1 \mathrm{~V}$ is most likely due to reduction of $\mathrm{Cu}$ (II) to $\mathrm{Cu}(\mathrm{I})$. Although copper is generally considered to be electrochemically inactive in CuHCF, reduction of $\mathrm{Cu}$ (II) to $\mathrm{Cu}(\mathrm{I})$ at low potentials has been reported. ${ }^{49,50}$ X-Ray absorption spectroscopy (XAS) of CuHCF on both metal centers show copper redox activity. ${ }^{50} \mathrm{Cu}(\mathrm{I})$ is observed even in the pristine sample, which has also been reported in other studies using X-ray absorption near edge structure (XANES). ${ }^{51,52}$

Fig. 3 shows the discharge capacity and coulombic efficiency as a function of cycle number. The capacity retention for the cell with voltage range $0.8-1.9 \mathrm{~V}$ is the poorest. Ferro/ferri-cyanide $\left(\left[\mathrm{Fe}(\mathrm{CN})_{6}\right]^{4-}\right.$ and $\left.\left[\mathrm{Fe}(\mathrm{CN})_{6}\right]^{3-}\right)$ do not form insoluble PBA with monovalent ions, including $\mathrm{Cu}(\mathrm{I}),{ }^{53}$ indicating that reduction of copper may result in increased solubility. Therefore, if the plateau at $1.1 \mathrm{~V}$ is due to reduction of copper, the poor capacity retention of cells discharged below $1.4 \mathrm{~V}$ may be caused by dissolution of CuHCF into the electrolyte.

The cell with the cut-off voltages $1.4 \mathrm{~V}$ and $1.9 \mathrm{~V}$ has the lowest initial capacity, which is limited by the upper cut-off voltage. Once it is allowed to charge to $2.0 \mathrm{~V}$, the capacity reaches the same level as other cells charged to $2.0 \mathrm{~V}$, see Fig. 3. The cells with voltage ranges $1.4-2.0 \mathrm{~V}$ and $1.4-2.05 \mathrm{~V}$ have a similar capacity retention which is higher than for the cells charged to only $1.9 \mathrm{~V}$. Still, for cells charged to $2.0 \mathrm{~V}$ and $2.05 \mathrm{~V}$, a new plateau at high state-of-charge appears at approximately $1.95 \mathrm{~V}$ after 50 cycles, and will be discussed later.

The coulombic efficiency is relatively high and increases slowly with cycle number. By cycle 150, all cells have an efficiency above $98 \%$, except the cell with voltage range 1.4-2.0 V. The cell 

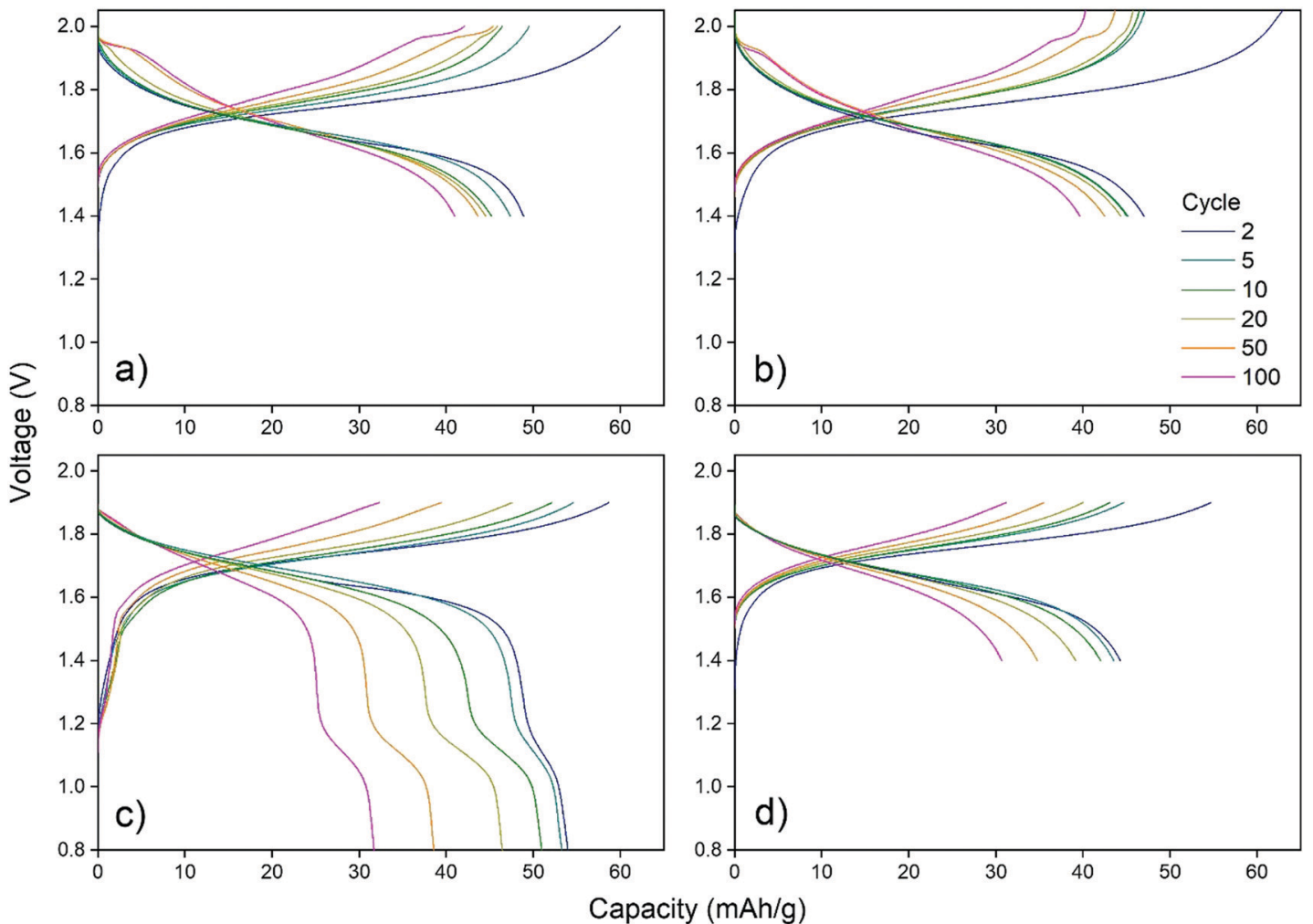

Fig. 2 Effect of voltage ranges $1.4-2.0 \mathrm{~V}, 1.4-2.05 \mathrm{~V}, 0.8-1.9 \mathrm{~V}$ and $1.4-1.9 \mathrm{~V}$ on $\mathrm{CuHCF} / \mathrm{Zn}$ cells with $1 \mathrm{M} \mathrm{ZnSO} \mathrm{Z}_{4}$ electrolyte at pH 4. CuHCF is sample $\mathrm{K}$.

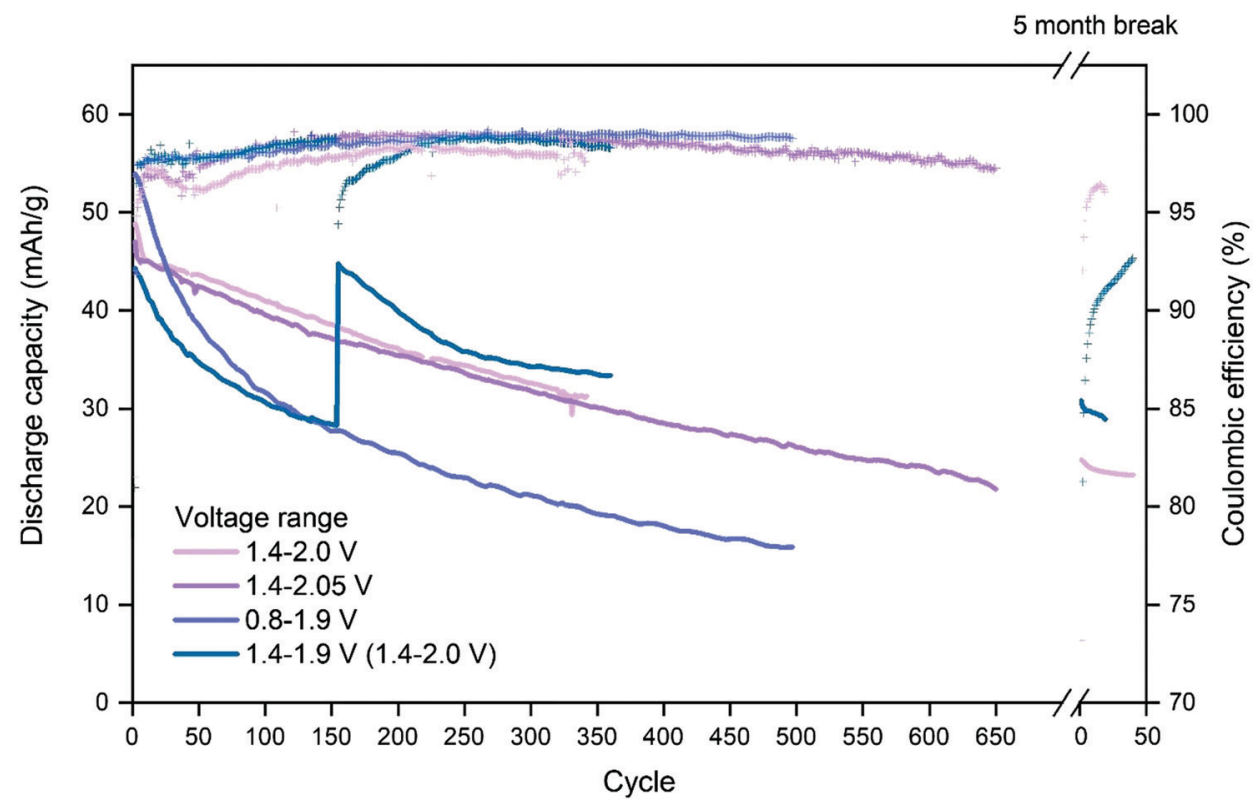

Fig. 3 Effect of voltage range on the cycle life of $\mathrm{CuHCF} / \mathrm{Zn}$ cells with $1 \mathrm{M} \mathrm{ZnSO}_{4}$ electrolyte at $\mathrm{pH} 4$. CuHCF is sample $\mathrm{K}$. After 154 cycles the cut-off voltage of the cell cycled in voltage range $1.4-1.9 \mathrm{~V}$ is increased to $2.0 \mathrm{~V}$, resulting in an increase in capacity.

cycled with voltage range $1.4-2.05 \mathrm{~V}$ has a high coulombic efficiency similar to the ones with a cutoff voltage of $1.9 \mathrm{~V}$, which shows that there is no significant gas evolution in the cell, and charging voltages up to $2.05 \mathrm{~V}$ appears safe.
After cycling for $\sim 350$ cycles, corresponding to approximately three weeks of cycling, the cell with cut-off voltage 1.4-2.0 is stopped and for five months after which the cycling is resumed with the same conditions. It is observed that the 
Table 3 Effect of voltage range on capacity retention of CuHCF/Zn cells with $1 \mathrm{M} \mathrm{ZnSO}_{4}$ electrolyte at $\mathrm{pH} 4$. CuHCF is sample $\mathrm{K}$

Initial capacity Capacity retention Capacity retention

Voltage range Cycle $2\left[\mathrm{~mA} \mathrm{~h}\right.$ Cycle $50\left[\mathrm{~mA} \mathrm{~h} \mathrm{~g}^{-1}\right.$ Cycle $100\left[\mathrm{~mA} \mathrm{~h} \mathrm{~g}^{-1}\right.$

\begin{tabular}{llll}
{$[\mathrm{V}]$} & $\left.\mathrm{g}^{-1}\right]$ & $(\%)]$ & $(\%)]$ \\
\hline $1.4-2.0$ & 49 & $44(90 \%)$ & $41(84 \%)$ \\
$1.4-2.05$ & 47 & $42(89 \%)$ & $40(85 \%)$ \\
$0.8-1.9$ & 54 & $39(72 \%)$ & $32(59 \%)$ \\
$1.4-1.9$ & 44 & $35(80 \%)$ & $31(70 \%)$
\end{tabular}

discharge capacity is similar to the capacity prior to the 5 months break, indicating that the decrease in capacity is an effect of cycling rather than an effect of time.

In Table 3, the capacity retention of cells with different voltage ranges are reported. The as-synthesized material is not fully charged, why the discharge capacity of the first cycle is low, and the discharge capacity of cycle two is therefore used as initial capacity.

\section{Effects of pH and electrolyte composition}

Four different CuHCF samples (C, G, I and K) are investigated as cathode material in $\mathrm{CuHCF} / \mathrm{Zn}$ cells with $1 \mathrm{M} \mathrm{Na} \mathrm{NO}_{4}$ electrolyte at $\mathrm{pH} 1,2$ and 4, and $1 \mathrm{M} \mathrm{ZnSO}_{4}$ electrolyte at pH 2 and 4 . All cells are cycled in the voltage range 1.4-2.0 $\mathrm{V}$ with a current of $50 \mathrm{~mA} \mathrm{~g}^{-1}$. Fig. 4 shows capacity/voltage plots, while the discharge capacity and coulombic efficiency as function of the cycle number is shown in Fig. 5 . The capacity retention of the different cells is summarized in Table 4 .
For cells tested in $\mathrm{Na}_{2} \mathrm{SO}_{4}$ based electrolyte, variation in $\mathrm{pH}$ has a large effect, and the capacity retention is significantly improved at lower $\mathrm{pH}$. All samples C, G, I and $\mathrm{K}$ have a very low capacity retention of maximum $29 \%$ after 50 cycles (see Table 4 ) in $\mathrm{Na}_{2} \mathrm{SO}_{4}$ electrolyte at $\mathrm{pH} 4$. At $\mathrm{pH} 2$, the capacity retention reaches a maximum of $69 \%$ after 50 cycles, and at pH 1 all cells achieve a high capacity retention ranging from $86 \%$ to $98 \%$ after 50 cycles. The decrease in capacity of $\mathrm{CuHCF} / \mathrm{Zn}$ cells with $\mathrm{Na}_{2} \mathrm{SO}_{4}$ based electrolyte at higher $\mathrm{pH}$ is likely due to dissolution of copper hexacyanoferrate. Dissolution of PBA in aqueous $\mathrm{Na}_{2} \mathrm{SO}_{4}$ electrolyte has previously been observed: Zhang et al. detected free $\left[\mathrm{Fe}(\mathrm{CN})_{6}\right]^{3-}$ by UV-vis spectroscopy after cycling ZnHCF in aqueous $\mathrm{Na}_{2} \mathrm{SO}_{4}$ and $\mathrm{K}_{2} \mathrm{SO}_{4}$ electrolytes. ${ }^{12}$ It should be noted that contrary to the results obtained here, a previous study on NiHCF in $\mathrm{Na}_{2} \mathrm{SO}_{4}$ electrolyte report similar performance at neutral $\mathrm{pH}$ and at $\mathrm{pH} 2 .^{41}$

Lowering the $\mathrm{pH}$ of the $\mathrm{Na}_{2} \mathrm{SO}_{4}$ electrolyte improves the capacity retention, indicating that dissociation is limited by lowering the $\mathrm{pH}$. At low $\mathrm{pH}$ copper exists as $\mathrm{Cu}^{2+}$, whereas at higher $\mathrm{pH}$ copper precipitates as $\mathrm{Cu}(\mathrm{OH})_{2}$. Precipitation of $\mathrm{Cu}(\mathrm{OH})_{2}$ drives the equilibrium towards further dissolution of CuHCF, as shown in Scheme 1.

For cells with $\mathrm{ZnSO}_{4}$ based electrolyte there are no significant differences between $\mathrm{pH} 2$ and $\mathrm{pH} 4$, and the capacity retention is significantly better than for corresponding cells with $\mathrm{Na}_{2} \mathrm{SO}_{4}$ based electrolyte. It seems likely that a degree of PBA dissolution occurs in both $\mathrm{ZnSO}_{4}$ and $\mathrm{Na}_{2} \mathrm{SO}_{4}$ electrolyte, however in the presence of $\mathrm{M}^{2+}$ ions such as $\mathrm{Zn}^{2+}$, free $\left[\mathrm{Fe}(\mathrm{CN})_{6}\right]^{3-}$ would immediately precipitate as zinc hexacyanoferrate ( $\mathrm{ZnHCF})$.

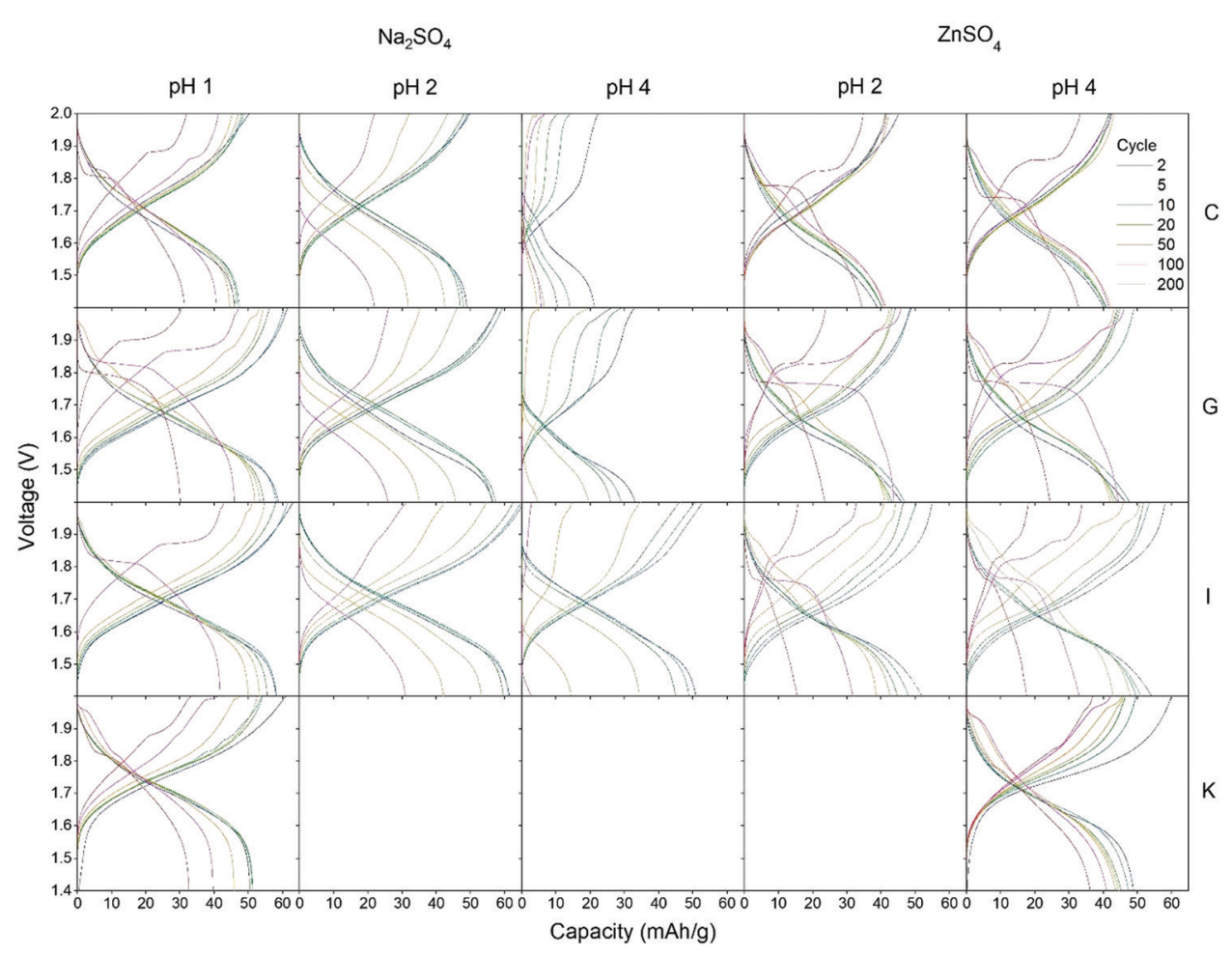

Fig. 4 Capacity/voltage plots for the four different CuHCF samples $\mathrm{C}, \mathrm{G}, \mathrm{I}$ and $\mathrm{K}$ as cathode material in CuHCF/Zn cells with $\mathrm{Na}_{2} \mathrm{SO}_{4}$ electrolyte at pH 1 , 2 and 4, and $\mathrm{ZnSO}_{4}$ electrolyte at $\mathrm{pH} 2$ and 4. Cells are cycled in the voltage range 1.4-2.0 V with a current rate of $50 \mathrm{~mA} \mathrm{~g}$. 


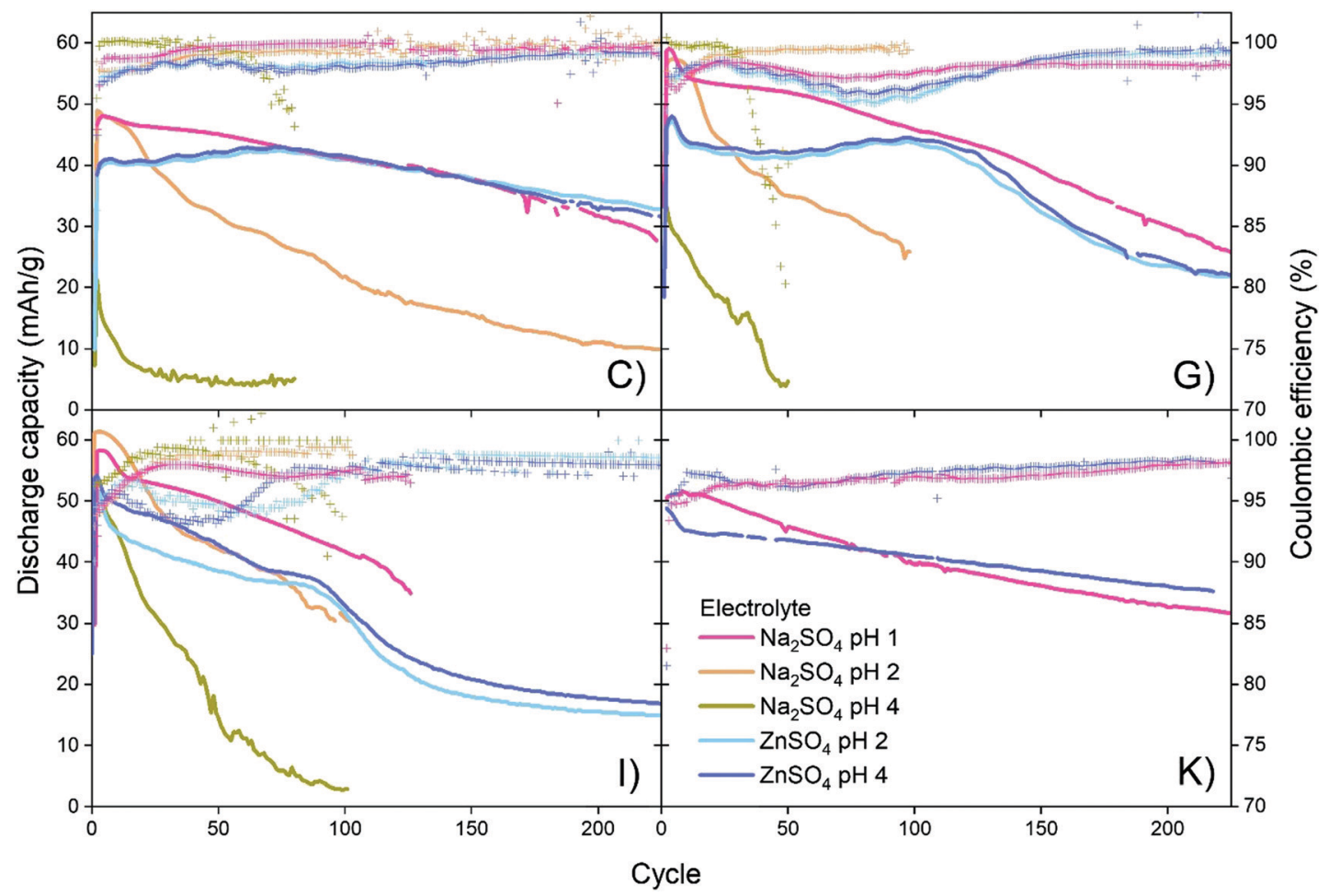

Fig. 5 Discharge capacity and coulombic efficiency as a function of cycle for the four different CuHCF samples $\mathrm{C}, \mathrm{G}, \mathrm{I}$ and $\mathrm{K}$ as cathode material in CuHCF/Zn cells with $\mathrm{Na}_{2} \mathrm{SO}_{4}$ electrolyte at $\mathrm{pH} 1,2$ and 4, and $\mathrm{ZnSO}_{4}$ electrolyte at $\mathrm{pH} 2$ and 4. Cells are cycled in the voltage range 1.4-2.0 V with a current rate of $50 \mathrm{~mA} \mathrm{~g}^{-1}$.

For cells with $\mathrm{Na}_{2} \mathrm{SO}_{4}$ based electrolyte, the concentration of $\mathrm{Zn}^{2+}$ is low and dependent on the state of charge. When the cell is fully charged, the $\mathrm{Zn}^{2+}$ concentration in the electrolyte is zero, while when fully discharged, the concentration of $\mathrm{Zn}^{2+}$ is estimated to be maximum $0.1 \mathrm{M}$, see calculation in ESI. $\dagger$ Due to the fact that the cell does not reach equilibrium during charge and discharge, there will be a $\mathrm{Zn}^{2+}$ concentration gradient with the highest concentrations towards the anode side. We suggest that the poor capacity retention of $\mathrm{CuHCF} / \mathrm{Zn}$ cells with $\mathrm{Na}_{2} \mathrm{SO}_{4}$ based electrolyte may be explained by diffusion of $\left[\mathrm{Fe}(\mathrm{CN})_{6}\right]^{3-}$ to the separator or anode where it precipitates as ZnHCF and becomes electrochemically inaccessible. For cells with $\mathrm{ZnSO}_{4}$ based electrolyte, $\mathrm{Zn}^{2+}$ is present at both the cathode and anode at all times, and ZnHCF is primarily precipitated at the cathode where it remains electrochemically accessible, explaining the improved capacity retention compared to cells with $\mathrm{Na}_{2} \mathrm{SO}_{4}$ electrolyte.

With reference to the model in Scheme 1 , it is somewhat surprising that the $\mathrm{CuHCF} / \mathrm{Zn}$ cells with $\mathrm{Na}_{2} \mathrm{SO}_{4}$ at $\mathrm{pH} 1$ develop a plateau at $1.85 \mathrm{~V}$ indicating formation of ZnHCF. It is speculated that this could be explained by the low $\mathrm{pH}$ value, which increases the reaction rate between $\mathrm{H}^{+}$and $\mathrm{Zn}$ to form $\mathrm{H}_{2}$ and $\mathrm{Zn}^{2+}$ that diffuses to the cathode side to form $\mathrm{ZnHCF}$. This is supported by the fact that the CuHCF/Zn cells with $\mathrm{Na}_{2} \mathrm{SO}_{4}$ electrolyte at $\mathrm{pH} 1$ fail after a maximum of 300 cycles, which could be a consequence of $\mathrm{H}_{2}$ evolution, eventually leading to loss of electrical/ionic contact in the cell.

In Fig. 4 it is seen that most of the $\mathrm{CuHCF} / \mathrm{Zn}$ cells with $\mathrm{ZnSO}_{4}$ electrolyte develop a new plateau at $\sim 1.95 \mathrm{~V}$ after $20-50$ cycles, as was also observed for cells charged to $2.0 \mathrm{~V}$ and $2.05 \mathrm{~V}$ in Fig. 2. After approximately 50-100 cycles, another plateau at $\sim 1.85 \mathrm{~V}$ develops for $\mathrm{CuHCF} / \mathrm{Zn}$ cells based on samples $\mathrm{C}, \mathrm{G}$ and I with $\mathrm{ZnSO}_{4}$ electrolyte. The appearance of the plateau at $1.85 \mathrm{~V}$ coincides with an apparent increase in the cell voltage. Additionally, in Fig. 5 a kink is seen for samples C, G and I around cycle 75-100 in the capacity versus cycle number. This is followed by a faster capacity decrease, while the coulombic efficiency increases. The appearance of the new plateau is likely to be related to formation of $\mathrm{ZnHCF}$, which has a standard potential that is approximately $0.15 \mathrm{~V}$ higher than that of $\mathrm{CuHCF},{ }^{54}$ in agreement with the apparent increase in cell voltage. Formation of M-HCF during cycling of PBA in aqueous $\mathrm{M}^{2+}$ electrolyte is supported by previous studies. ${ }^{45,55}$ For the sample $\mathrm{K}$ cell with $\mathrm{ZnSO}_{4}$ electrolyte, a plateau at $1.95 \mathrm{~V}$ appears after $20-50$ cycles. However the plateau at $1.85 \mathrm{~V}$ has not developed after 200 cycles but it is observed after 400 cycles (see Fig. S3, ESI $\dagger$ ).

Besides CuHCF dissolution, other models for $\mathrm{ZnHCF}$ formation have been proposed. One suggested mechanism proposes $\mathrm{ZnHCF}$ nucleation at vacant $\left[\mathrm{Fe}(\mathrm{CN})_{6}\right]^{3-/ 4-}$ positions within the $\mathrm{CuHCF}$ framework, resulting in a mixed copper/zinc hexacyanoferrate. ${ }^{45}$ Another possible mechanism explains the formation of mixed hexacyanoferrates as a distortion of the PBA lattice caused by the presence of $\mathrm{M}^{2+}$ in the interstitial (A) sites, which allows substitution of lattice transition metals. ${ }^{56}$ In the present study, we find no systematic differences between $\mathrm{CuHCF} / \mathrm{Zn}$ cells (samples $\mathrm{C}, \mathrm{G}$ and I) with $\mathrm{ZnSO}_{4}$ electrolyte at $\mathrm{pH} 2$ and 4 . If $\mathrm{ZnHCF}$ forms by nucleating at vacant $\left[\mathrm{Fe}(\mathrm{CN})_{6}\right]^{3-/ 4-}$ sites, minimizing vacancies 
Table 4 Effect of $\mathrm{pH}$ on the cycle life of different CuHCF/Zn cells. The capacity retention is calculated with respect to the initial capacity (cycle 2)

\begin{tabular}{|c|c|c|c|c|}
\hline \multirow[b]{2}{*}{ Sample } & \multirow{2}{*}{$\begin{array}{l}\text { Initial } \\
\text { capacity } \\
{\left[\mathrm{mA} \mathrm{h} \mathrm{g}^{-1}\right]}\end{array}$} & \multicolumn{3}{|c|}{$\begin{array}{l}\text { Capacity retention } \\
{\left[\mathrm{mA} \mathrm{h} \mathrm{g}^{-1}(\%)\right]}\end{array}$} \\
\hline & & Cycle 50 & Cycle 100 & Cycle 200 \\
\hline Sample C $\mathrm{Na}_{2} \mathrm{SO}_{4}$ pH 1 & 46 & $45(98 \%)$ & $41(89 \%)$ & $32(70 \%)$ \\
\hline Sample $\mathrm{C} \mathrm{Na}_{2} \mathrm{SO}_{4}$ pH 2 & 49 & $32(65 \%)$ & $22(45 \%)$ & - \\
\hline Sample C $\mathrm{Na}_{2} \mathrm{SO}_{4} \mathrm{pH} 4$ & 21 & $4(19 \%)$ & - & - \\
\hline Sample C $\mathrm{ZnSO}_{4}$ pH 2 & 39 & $42(108 \%)$ & $41(105 \%)$ & $34(87 \%)$ \\
\hline Sample C $\mathrm{ZnSO}_{4} \mathrm{pH} 4$ & 38 & $42(111 \%)$ & $42(111 \%)$ & $33(87 \%)$ \\
\hline Sample $\mathrm{G} \mathrm{Na}_{2} \mathrm{SO}_{4} \mathrm{pH} 1$ & 59 & $52(88 \%)$ & $46(78 \%)$ & $30(51 \%)$ \\
\hline Sample $\mathrm{G} \mathrm{Na}_{2} \mathrm{SO}_{4}$ pH 2 & 57 & $35(61 \%)$ & $26(46 \%)^{a}$ & - \\
\hline Sample $\mathrm{G} \mathrm{Na}_{2} \mathrm{SO}_{4}$ pH 4 & 33 & $5(15 \%)$ & - & - \\
\hline Sample $\mathrm{G} \mathrm{ZnSO}_{4} \mathrm{pH} 2$ & 46 & $41(89 \%)$ & $44(96 \%)$ & $24(52 \%)$ \\
\hline Sample $\mathrm{G} \mathrm{ZnSO}_{4} \mathrm{pH} 4$ & 46 & $42(91 \%)$ & $44(96 \%)$ & $24(52 \%)$ \\
\hline Sample I $\mathrm{Na}_{2} \mathrm{SO}_{4} \mathrm{pH} 1$ & 58 & $50(86 \%)$ & $42(72 \%)$ & - \\
\hline Sample I $\mathrm{Na}_{2} \mathrm{SO}_{4}$ pH 2 & 61 & $42(69 \%)$ & $31(51 \%)$ & - \\
\hline Sample I $\mathrm{Na}_{2} \mathrm{SO}_{4} \mathrm{pH} 4$ & 51 & $15(29 \%)$ & $3(6 \%)$ & - \\
\hline Sample I $\mathrm{ZnSO}_{4}$ pH 2 & 51 & $39(76 \%)$ & $32(63 \%)$ & $16(31 \%)$ \\
\hline Sample I $\mathrm{ZnSO}_{4} \mathrm{pH} 4$ & 54 & $43(80 \%)$ & $33(61 \%)$ & $18(33 \%)$ \\
\hline Sample $\mathrm{K} \mathrm{Na}_{2} \mathrm{SO}_{4}$ pH 1 & 50 & $46(92 \%)$ & $40(80 \%)$ & $33(66 \%)$ \\
\hline Sample $\mathrm{K} \mathrm{ZnSO}_{4} \mathrm{pH} 4$ & 49 & $44(90 \%)$ & $41(84 \%)$ & $36(73 \%)$ \\
\hline
\end{tabular}

$$
\begin{aligned}
& \qquad \mathrm{Cu}^{2+}+\frac{2}{3} \mathrm{Fe}(\mathrm{CN})_{6}{ }^{3-} \longleftrightarrow \mathrm{Cu}\left[\mathrm{Fe}(\mathrm{CN})_{6}\right]_{\frac{2}{3}} \\
& \begin{array}{l}
\text { At low pH the equilibrium } \\
\text { is shifted towards } \mathrm{Cu}^{2+}
\end{array} \overbrace{\mathrm{Cu}(\mathrm{OH})_{2}} \mathrm{Zn}\left[\mathrm{Fe}(\mathrm{CN})_{6}\right]_{\frac{2}{3}}
\end{aligned}
$$

Scheme 1 Proposed mechanism for capacity loss of CuHCF/Zn cells.

may prevent/decrease ZnHCF formation. Cycling of an almost vacancy free $\mathrm{MnHCF} / \mathrm{Zn}$ cell with $\mathrm{ZnSO}_{4}$ electrolyte proves that low-vacancy PBA can indeed intercalate Zn-ions, see ESI $\dagger$ (Fig. S6). If on the other hand transition metal substitution is due to lattice distortion caused by $\mathrm{M}^{2+}$ insertion, the number of vacancies should have no effect on the extent of ZnHCF formation. Depending on the mechanism for ZnHCF formation, different strategies could be attempted to limit ZnHCF formation. In a study of CoHCF with $1 \mathrm{M} \mathrm{Na}_{2} \mathrm{SO}_{4}$ electrolyte, the capacity retention was improved by addition of $1 \mathrm{wt} \% \mathrm{CoSO}_{4}$ to the electrolyte, ${ }^{57}$ probably because the existence of $\mathrm{Co}^{2+}$ ions in the electrolyte allows free $\left[\mathrm{Fe}(\mathrm{CN})_{6}\right]^{3-}$ to precipitate with $\mathrm{Co}^{2+}$ as CoHCF. By analogy, M-HCF/Zn cells may benefit from addition of $\mathrm{MSO}_{4}$ to the $\mathrm{Na}_{2} \mathrm{SO}_{4}$ electrolyte, however in the case of $\mathrm{CuHCF}$, addition of $\mathrm{CuSO}_{4}$ would lead to copper electroplating on the anode side due to the higher redox potential of the $\mathrm{Cu} / \mathrm{Cu}^{2+}$ redox pair compared to $\mathrm{Zn} / \mathrm{Zn}^{2+}$.

Previous studies have reported that decreasing the $\mathrm{Zn}^{2+}$ concentration in the electrolyte increases the cycle life of $\mathrm{CuHCF} / \mathrm{Zn}$ cells. ${ }^{13,45}$ In a study comparing CuHCF/Zn cells in $\mathrm{ZnSO}_{4}$ and $\mathrm{Na}_{2} \mathrm{SO}_{4}$ based electrolytes, the best cycle life was achieved with $1 \mathrm{M}$ $\mathrm{Na}_{2} \mathrm{SO}_{4}$ electrolyte acidified with $0.01 \mathrm{M} \mathrm{H}_{2} \mathrm{SO}_{4} \cdot{ }^{13}$ In the present study, the capacity retention is not improved by using $\mathrm{Na}_{2} \mathrm{SO}_{4}$ electrolyte compared to $\mathrm{ZnSO}_{4}$ electrolyte. It should be noted that the capacity retentions reported in different studies are not directly comparable due to differences in electrolyte concentration and different current rates.

\section{Sample dependence}

As noted previously, the plateau at approximately $1.85 \mathrm{~V}$ develops much later for cells with sample K cathode than for cells with samples C, G and I (Fig. 4). After 200 cycles, the capacity of $\mathrm{CuHCF} / \mathrm{Zn}$ cells with $\mathrm{ZnSO}_{4}$ electrolyte based on samples G and I has decreased dramatically, while sample $\mathrm{C}$ and sample $\mathrm{K}$ retain a capacity retention of $87 \%$ and $73 \%$, respectively. The capacity retention of $\mathrm{CuHCF} / \mathrm{Zn}$ cells seems closely linked to the development of the new plateau at $1.85 \mathrm{~V}$, related to formation of ZnHCF. After 200 cycles, only the cell with sample $\mathrm{K}$ cathode has not developed a plateau at $1.85 \mathrm{~V}$ in $\mathrm{ZnSO}_{4}$ electrolyte. The $\mathrm{CuHCF} / \mathrm{Zn}$ cell with $\mathrm{ZnSO}_{4}$ electrolyte at $\mathrm{pH} 4$ with sample $\mathrm{C}$ and sample $\mathrm{K}$ both have a high capacity retention, however, after approximately 75 cycles, the capacity starts decreasing more rapidly for sample C. After 140 cycles the capacity of sample $\mathrm{K}$ is higher than that of sample C, see Fig. S1 (ESI $\dagger$ ).

It has previously been reported that PBA with a smaller particle size have a higher initial capacity, ${ }^{58-60}$ while a larger particle size improves capacity retention. ${ }^{60}$ In the present case, we do not see any clear correlation between performance and particle size. With an average particle size of $53 \mathrm{~nm}$, sample G has the largest particle size, whereas the other samples are similar in size $(32-37 \mathrm{~nm})$.

As mentioned previously, it is known that larger cations such as $\mathrm{Zn}^{2+}$ can migrate through vacant $\left[\mathrm{Fe}(\mathrm{CN})_{6}\right]^{3-14-}$ positions. ${ }^{35,36}$ Therefore, the number of vacancies could potentially be important for the electrochemical performance. The difference in the number of vacancies for CuHCF samples is at the edge of the experimental resolution. Nonetheless, the number of vacancies in sample $\mathrm{K}$ is slightly lower than that of samples C, G and I. This could possibly be a result of the synthesis from $\mathrm{Fe}$ (II) and not $\mathrm{Fe}$ (III) as for the other samples. In addition to the number of vacancies, also the vacancy distribution could affect electrochemical performance. As shown by Simonov et al., PBA tend to have a nonrandom vacancy ordering. ${ }^{33}$ Vacancy ordering may be affected by synthesis parameters, and could therefore be different for the samples included here.

It remains an interesting question what exactly causes the difference in performance, but here we conclude that performance of $\mathrm{CuHCF} / \mathrm{Zn}$ cells is highly dependent on the CuHCF sample, and very different performance is observed even for relatively similar samples.

\section{Conclusion}

For CuHCF/Zn cells with $\mathrm{ZnSO}_{4}$ based electrolyte, there is negligible difference in performance at $\mathrm{pH} 2$ and 4 . In $\mathrm{Na}_{2} \mathrm{SO}_{4}$ based electrolyte, the performance is improved significantly at lower $\mathrm{pH}$, which is likely due to decreased dissolution at lower pH. PBA dissolution is likely to occur also in $\mathrm{ZnSO}_{4}$ based electrolyte, but due to the presence of $\mathrm{Zn}^{2+}$ ions in the electrolyte, 
free $\left[\mathrm{Fe}(\mathrm{CN})_{6}\right]^{3-/ 4-}$ react immediately and precipitate as ZnHCF. Contrary to previous reports, the capacity retention is not improved by using $\mathrm{Na}_{2} \mathrm{SO}_{4}$ electrolyte rather than $\mathrm{ZnSO}_{4}$ electrolyte.

After extended cycling, all $\mathrm{CuHCF} / \mathrm{Zn}$ cells develop a new plateau in the voltage profile at approximately $1.85 \mathrm{~V}$, which is attributed to the formation of a new ZnHCF phase. For CuHCF/ Zn cells with sample $\mathrm{K}$ cathode, the plateau appears much later than for the others, resulting in superior capacity retention. The synthesis of sample $\mathrm{K}$ differs from the others in three ways: (1) whereas samples C, G and I were prepared in the oxidized form $\left(\mathrm{Cu}^{\mathrm{II}}\left[\mathrm{Fe}^{\mathrm{III}}(\mathrm{CN})_{6}\right]_{1-y}\right)$, sample $\mathrm{K}$ was initially prepared in the reduced form $\left(\mathrm{Cu}^{\mathrm{II}}\left[\mathrm{Fe}^{\mathrm{II}}(\mathrm{CN})_{6}\right]_{1-y}\right)$ and was subsequently oxidized using excess hydrogen peroxide. (2) For samples C, $\mathrm{G}$ and $\mathrm{I}$ a $\mathrm{CuSO}_{4}$ precursor was used, whereas for sample $\mathrm{K}$ the precursor was $\mathrm{CuCl}_{2}$. (3) The flow rate for precursor addition was $1 \mathrm{~mL} \min ^{-1}$ for sample $\mathrm{K}$ and $4 \mathrm{~mL} \mathrm{~min}^{-1}$ for samples $\mathrm{C}$, $\mathrm{G}$ and $\mathrm{I}$. Either of these differences could potentially cause the different performance in $\mathrm{CuHCF} / \mathrm{Zn}$ cells, and invites further study.

CuHCF samples have surprisingly different performance. Structural analysis does not reveal significant differences to account for the different performance of CuHCF samples C, G, I and K. As shown by Simonov et al., PBA exhibit non-random vacancy ordering, which may be affected by synthesis conditions, $^{33}$ and studies of PBA linking vacancy ordering and electrochemical performance could potentially reveal information about the mechanisms for the different properties of apparently similar samples.

\section{Conflicts of interest}

There are no conflicts to declare.

\section{References}

1 P. C. K. Vesborg and T. F. Jaramillo, RSC Adv., 2012, 2, 7933.

2 London Metal Exchange, https://www.lme.com/en-GB/ Metals/Non-ferrous\#tabIndex $=\mathbf{0}$.

3 M. Huang, M. Li, C. Niu, Q. Li and L. Mai, Adv. Funct. Mater., 2019, 29, 1807847.

4 H. Pan, Y. Shao, P. Yan, Y. Cheng, K. S. Han, Z. Nie, C. Wang, J. Yang, X. Li, P. Bhattacharya, K. T. Mueller and J. Liu, Nat. Energy, 2016, 1, 16039.

5 W. Sun, F. Wang, S. Hou, C. Yang, X. Fan, Z. Ma, T. Gao, F. Han, R. Hu, M. Zhu and C. Wang, J. Am. Chem. Soc., 2017, 139, 9775-9778.

6 J. K. Seo, J. Shin, H. Chung, P. Y. Meng, X. Wang and Y. S. Meng, J. Phys. Chem. C, 2018, 122, 11177-11185.

7 D. Kundu, B. D. Adams, V. Duffort, S. H. Vajargah and L. F. Nazar, Nat. Energy, 2016, 1, 16119.

8 Z. Jia, B. Wang and Y. Wang, Mater. Chem. Phys., 2015, 149-150, 601-606.

9 L.-P. Wang, P.-F. Wang, T.-S. Wang, Y.-X. Yin, Y.-G. Guo and C.-R. Wang, J. Power Sources, 2017, 355, 18-22.
10 L. Zhang, L. Chen, X. Zhou and Z. Liu, Sci. Rep., 2015, 5, 18263. 11 R. Trócoli and F. La Mantia, ChemSusChem, 2015, 8, 481-485.

12 L. Zhang, L. Chen, X. Zhou and Z. Liu, Adv. Energy Mater., 2015, 5, 1400930.

13 T. Gupta, A. Kim, S. Phadke, S. Biswas, T. Luong, B. J. Hertzberg, M. Chamoun, K. Evans-Lutterodt and D. A. Steingart, J. Power Sources, 2016, 305, 22-29.

14 K. Lu, B. Song, J. Zhang and H. Ma, J. Power Sources, 2016, 321, 257-263.

15 J. F. Keggin and F. D. Miles, Nature, 1936, 137, 577-578.

16 C. D. Wessells, R. A. Huggins and Y. Cui, Nat. Commun., $2011,2,550$.

17 X. Wu, Y. Luo, M. Sun, J. Qian, Y. Cao, X. Ai and H. Yang, Nano Energy, 2015, 13, 117-123.

18 Y. Yang, E. Liu, X. Yan, C. Ma, W. Wen, X.-Z. Liao and Z.-F. Ma, J. Electrochem. Soc., 2016, 163, A2117-A2123.

19 D. Yang, J. Xu, X.-Z. Liao, Y.-S. He, H. Liu and Z.-F. Ma, Chem. Commun., 2014, 50, 13377-13380.

20 R. Chen, Y. Huang, M. Xie, Z. Wang, Y. Ye, L. Li and F. Wu, ACS Appl. Mater. Interfaces, 2016, 8, 31669-31676.

21 C. Li, R. Zang, P. Li, Z. Man, S. Wang, X. Li, Y. Wu, S. Liu and G. Wang, Chem. - Asian J., 2018, 13, 342-349.

22 X. Wu, C. Wu, C. Wei, L. Hu, J. Qian, Y. Cao, X. Ai, J. Wang and H. Yang, ACS Appl. Mater. Interfaces, 2016, 8, 5393-5399.

23 Y. You, X. Wu, Y. Yin and Y. Guo, Energy Environ. Sci., 2014, 7, 1643-1647.

24 Z. Ji, B. Han, H. Liang, C. Zhou, Q. Gao, K. Xia and J. Wu, ACS Appl. Mater. Interfaces, 2016, 8, 33619-33625.

25 H.-W. Lee, R. Y. Wang, M. Pasta, S. Woo Lee, N. Liu and Y. Cui, Nat. Commun., 2014, 5, 5280.

26 Y. Moritomo, Y. Kurihara, T. Matsuda and J. Kim, J. Phys. Soc. Jpn., 2011, 80, 103601.

27 R. Y. Wang, B. Shyam, K. H. Stone, J. N. Weker, M. Pasta, H. Lee, M. F. Toney and Y. Cui, Adv. Energy Mater., 2015, 5, 1401869.

28 M. Pasta, C. D. Wessells, R. A. Huggins and Y. Cui, Nat. Commun., 2012, 3, 1149.

29 A. Zhou, Z. Xu, H. Gao, L. Xue, J. Li and J. B. Goodenough, Small, 2019, 15, 1902420.

30 H. L. B. Boström, I. E. Collings, A. B. Cairns, C. P. Romao and A. L. Goodwin, Dalton Trans., 2019, 48, 1647-1655.

31 S. S. Kaye and J. R. Long, J. Am. Chem. Soc., 2005, 127, 6506-6507.

32 C. P. Krap, J. Balmaseda, L. F. del Castillo, B. Zamora and E. Reguera, Energy Fuels, 2010, 24, 581-589.

33 A. Simonov, T. De Baerdemaeker, H. L. B. Boström, M. L. Ríos Gómez, H. J. Gray, D. Chernyshov, A. Bosak, H.-B. Bürgi and A. L. Goodwin, Nature, 2020, 578, 256-260. 34 S. C. van der Marck, Int. J. Mod. Phys. C, 1998, 09, 529-540. 35 Y. Moritomo, K. Igarashi, J. Kim and H. Tanaka, Appl. Phys. Express, 2009, 2, 085001.

36 V. Renman, D. O. Ojwang, M. Valvo, C. P. Gómez, T. Gustafsson and G. Svensson, J. Power Sources, 2017, 369, 146-153.

37 J. Lim, G. Kasiri, R. Sahu, K. Schweinar, K. Hengge, D. Raabe, F. La Mantia and C. Scheu, Chem. - Eur. J., 2020, 26, 4917-4922. 
38 F. W. Thomas Goh, Z. Liu, T. S. A. Hor, J. Zhang, X. Ge, Y. Zong, A. Yu and W. Khoo, J. Electrochem. Soc., 2014, 161, A2080-A2086.

39 J. Ming, J. Guo, C. Xia, W. Wang and H. N. Alshareef, Mater. Sci. Eng., $R$, 2019, 135, 58-84.

40 D. E. Stilwell, K. H. Park and M. H. Miles, J. Appl. Electrochem., 1992, 22, 325-331.

41 P. Marzak, J. Yun, A. Dorsel, A. Kriele, R. Gilles, O. Schneider and A. S. Bandarenka, J. Phys. Chem. C, 2018, 122, 8760-8768.

42 S. Berchmans, H. Gomathi and G. P. Rao, J. Electroanal. Chem., 1995, 394, 267-270.

43 S.-M. Chen, C.-Y. Liou and R. Thangamuthu, Electroanalysis, 2007, 19, 2457-2464.

44 X. Zhou, S. Wang, Z. Wang and M. Jiang, Fresenius' J. Anal. Chem., 1993, 345, 424-427.

45 G. Kasiri, R. Trócoli, A. Bani Hashemi and F. La Mantia, Electrochim. Acta, 2016, 222, 74-83.

46 Y. Yang, C. Brownell, N. Sadrieh, J. May, A. Del Grosso, D. Place, E. Leutzinger, E. Duffy, R. He, F. Houn, R. Lyon and P. Faustino, Clin. Toxicol., 2007, 45, 776-781.

47 A. Mohammad, Y. Yang, M. A. Khan and P. J. Faustino, Clin. Toxicol., 2015, 53, 102-107.

48 S. Kjeldgaard, I. Dugulan, A. Mamakhel, M. Wagemaker, B. B. Iversen and A. Bentien, R. Soc. Open Sci., 2021, 8, 201779.

49 O. Makowski, J. Stroka, P. J. Kulesza, M. A. Malik and Z. Galus, J. Electroanal. Chem., 2002, 532, 157-164.
50 A. Mullaliu, G. Aquilanti, P. Conti, J. R. Plaisier, M. Fehse, L. Stievano and M. Giorgetti, J. Phys. Chem. C, 2018, 122, 15868-15877.

51 M. Giorgetti, L. Guadagnini, D. Tonelli, M. Minicucci and G. Aquilanti, Phys. Chem. Chem. Phys., 2012, 14, 5527.

52 J. Chaboy, A. Muñoz-Páez, F. Carrera, P. Merkling and E. S. Marcos, Phys. Rev. B: Condens. Matter Mater. Phys., 2005, 71, 1-7.

53 M. D. Adams and J. H. Kyle, Conf. Pap. Minprex 2000.

54 M. Jayalakshmi and F. Scholz, J. Power Sources, 2000, 91, 217-223.

55 A. Dostal, B. Meyer, F. Scholz, U. Schroeder, A. M. Bond, F. Marken and S. J. Shaw, J. Phys. Chem., 1995, 99, 2096-2103.

56 N. F. Zakharchuk, N. Naumov, R. Stösser, U. Schröder, F. Scholz and H. Mehner, J. Solid State Electrochem., 1999, 3, 264-276.

57 T. Shao, C. Li, C. Liu, W. Deng, W. Wang, M. Xue and R. Li, J. Mater. Chem. A, 2019, 7, 1749-1755.

58 G. He and L. F. Nazar, ACS Energy Lett., 2017, 2, 1122-1127. 59 P. Padigi, J. Thiebes, M. Swan, G. Goncher, D. Evans and R. Solanki, Electrochim. Acta, 2015, 166, 32-39.

60 M. Fiore, K. Hurlbutt, S. Wheeler, I. Capone, J. Fawdon, R. Ruffo and M. Pasta, Chem. Mater., 2020, 32(18), 7653-7661. 